\title{
Caves as geoheritage resource in remote desert areas: a preliminary evaluation of Djara Cave in the Western Desert of Egypt
}

\author{
Kholoud M. Abdel Maksoud ${ }^{1}$, Mahmoud I. Baghdadi ${ }^{2,3}$, Dmitry A. Ruban ${ }^{4,5 *}$ \\ ${ }^{1}$ Natural Resources Department, Faculty of Postgraduate African Studies, Cairo University, Giza, Cairo 12613, Egypt \\ 2 Shaybah Wildlife Sanctuary, Saudi Arabia \\ ${ }^{3}$ Ministry of Environment, 30 Misr Helwan El-Zyrae Road, Maadi, Cairo 11728, Egypt \\ ${ }^{4}$ K.G. Razumovsky Moscow State University of Technologies and Management (the First Cossack University), \\ Zemlyanoy Val Street 73, Moscow 109004, Russia \\ ${ }^{5}$ Higher School of Business, Southern Federal University, 23-ja Linija Street 43, Rostov-on-Don 344019, Russia \\ (postal address: P.O. Box 7333, Rostov-on-Don 344056, Russia) \\ *corresponding author; e-mail: ruban-d@mail.ru
}

\begin{abstract}
Caves are rare in northeast Africa and, thus, deserve attention as potential geoheritage objects (geosites). Assessment of Djara Cave and its vicinity (Western Desert, Egypt) has permitted to document unique features, such as the cave itself as a peculiar subsurface landform, speleothems providing data for palaeoenvironmental reconstructions, rock art demonstrating elements of past landscapes, siliceous nodules weathered from Eocene limestones and a network of dry drainage channels indicative of wetter palaeoenvironments. These features are assigned to geomorphological, sedimentological and palaeogeographical types of geoheritage. Djara Cave and its vicinity are proposed as a geosite of national rank; it is vulnerable to anthropogenic stress and needs geoconservation measures and instalment of interpretative signs. This geosite is already popular among tourists, and can be used for further tourism development. More generally, the presence of caves in Egyptian desert areas makes possible the recognition of national speleological heritage that requires special country-level strategies of management.
\end{abstract}

Key words: Desert cave, geomorphosite, rock art, siliceous nodules, tourism

\section{Introduction}

Caves are among the most popular objects of geoconservation and geotourism; relevant geoheritage features have been reported from numerous countries (Paunovic, 1996; Urban, 2004; Mügge et al., 2007; Garofano \& Govoni, 2012; Lobo \& Boggiani, 2013; Stephens et al., 2013; Wei et al., 2016; Ruban,
2018; Ballesteros et al., 2019; Lewis, 2019; Polukhina et al., 2019; Woo et al., 2019; Sallam et al., 2020; Čech et al., 2021). Such a popularity of caves can be linked, on the one hand, to excellent public awareness of such objects and their exceptional aesthetic properties, and, on the other, to their vulnerability to various types of damage. In northeast Africa and Egypt in particular, caves are not numerous, and 
this rarity itself stresses their uniqueness (Brook et al., 2002; Vermeersch et al., 2005; Classen et al., 2009; Schmidt et al., 2015; Yousif et al., 2018; Kharbish et al., 2020; Sallam et al., 2020; Ruban et al., 2021). Caves are often related to water action and, as such, they appear somewhat unexpected in a desert environment. Moreover, geoarchaeological peculiarities of these caves, including rock art, are essential for our understanding of past societies and their interaction with palaeoenvironments.

Djara Cave in the Western Desert (Fig. 1) is one of the best-known Egyptian caves on account of its speleological and geoarchaeological features and, particularly, speleothems of spectacular shapes and isotopic records, as well as Prehistoric rock art (Brook et al., 2002, 2003; Kindermann et al., 2006; Classen et al., 2009; Embabi, 2018). Although it is realised how unique this site is, a systematic geoheritage interpretation of it is needed in order to gauge its full heritage value, present state and geoconservation needs. New field investigations in Djara Cave and its vicinity have now allowed comprehensive geoheritage assessment, the results of which are summarised in the present paper. The main objective is to demonstrate the importance of this cave as a constituent of Egyptian geoheritage, as well as to stress its complexity and uniqueness beyond the cave itself.

\section{Geological setting}

The study area corresponds to the Djara Depression, which is situated on the Egyptian Limestone
Plateau (Fig. 1), being halfway between Asyut in the Nile Valley and the Farafra Oasis in the Western Desert. The area hosts hilltops, flat depressions, playa deposits, hamadas, dry drainage channels and sand dunes, which formed under hyper-arid conditions with short relatively wet phases during the late Quaternary (Kindermann et al., 2006). Djara Cave is located in the centre of the depression, with a narrow entrance on a gentle slope.

The study area is dominated by Eocene marine limestones which dip at very low angles to the northeast; sand dunes are typical to the eastern part of the area. The local geology is rather monotonous and characteristic to the Egyptian Limestone Plateau. The limestones formed on a wide shelf of the north African passive margin of the eastern Mediterranean; the sea regressed during the Oligocene and terrestrial conditions with uplifts and erosion prevailed later (Golonka, 2004; Guiraud et al., 2005; Said, 2017). Hyper-aridity and wind erosion have become typical since the Pleistocene (Brookes, 2001, 2003; Brook, 2003; Kindermann et al., 2006). Djara Cave illustrates the outcome of karst processes that accelerated during wet phases.

The Djara Depression is famous for its archaeological record, the development of which is strongly linked to Holocene climate variability (Gehlen et al., 2002; Kindermann et al., 2006). Several dozens of sites and a huge number of artefacts have been recorded; these are linked chiefly to human occupation of the study area during the Holocene humid optimum, and, particularly, to the period between 6,400 to 5,300 cal yr BC. Djara Cave itself is an im-

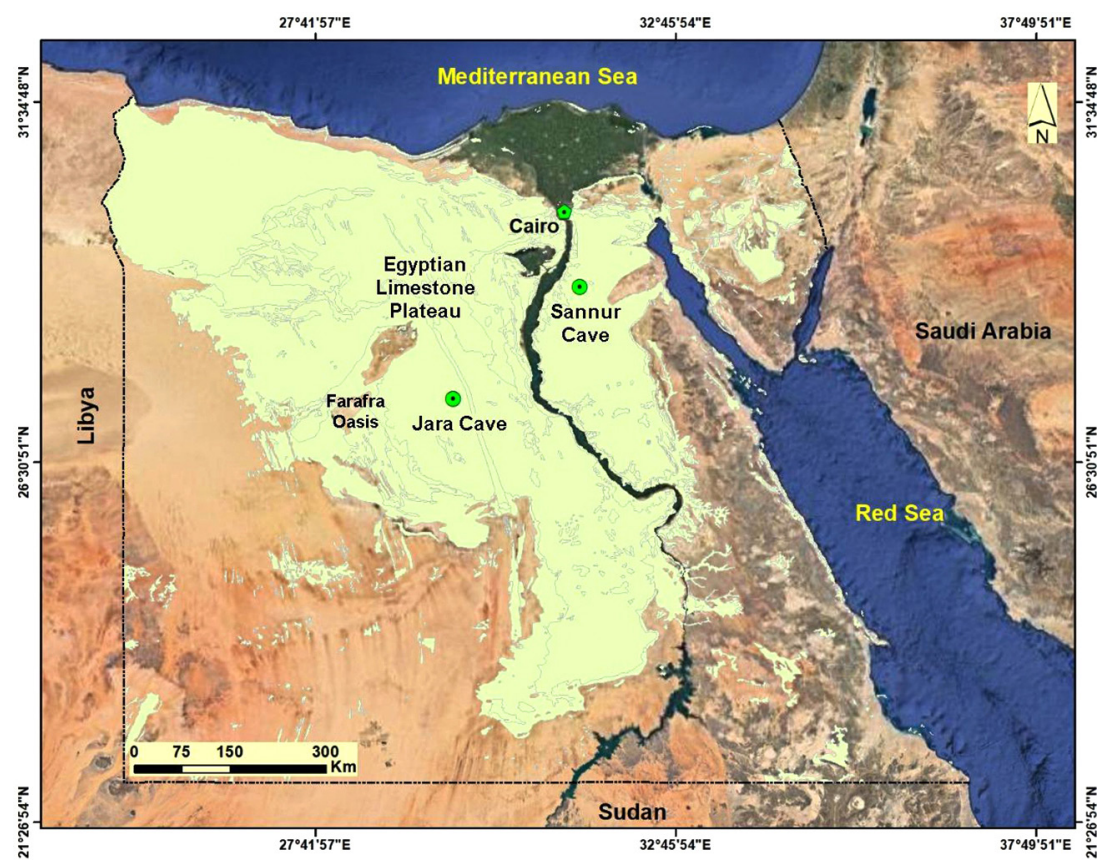

Fig. 1. Geographical location of the Djara Cave (source of the base satellite images: Google Earth Engine). 
portant archaeological site boasting rock art, as well as lithic artefacts and pottery (Kindermann et al., 2006; Classen et al., 2009; Embabi, 2018).

\section{Methodology}

The basic principles of geoheritage assessment have been explained by Prosser et al. (2006), Ruban (2010), Štrba et al. (2015), Brilha (2016) and Reynard \& Brilha (2018), among others. Nevetheless, the proposed approaches are case sensitive, and need to take into account the specific features of the unique objects characterised and peculiarities of the countries where these objects are found (e.g., Mikhailenko et al., 2021; Ruban et al., 2021). In the present note, the methodology proposed for and tested in other Egyptian caves, namely Sannur Cave (Sallam et al., 2020), is generally followed, with certain justification. The present study combines descriptive and qualitative approaches, which is typical of pioneering reports of new geoheritage objects. The quantitative approaches proposed earlier (e.g., Brilha, 2016; Warowna et al., 2016) are very useful conceptually and methodologically, but these are often justified to experience gained across Europe, and their application to Egypt and many other countries would be challenging. Moreover, such approaches suit territorial geoheritage assessment better, which is beyond the scope of the present study, which is based on the field investigations at Djara Cave and its vicinity.

All notable geomorphological, geological and geoarchaeological features were identified and documented for further geoheritage interpretation. Existing literature (Brook et al., 2002, 2003; Kindermann et al., 2006; Classen et al., 2009; Embabi, 2018) is also summarised and taken into account. Our study has required the construction of digital eleva- tion models for better representation of the terrain where Djara Cave is situated. For this purpose, the Advanced Spaceborne Thermal Emission and Reflection Radiometer (ASTER) and Global Digital Elevation Model (GDEM) were acquired as 1 scene/tile (N27_E029_1arc_v3) (source: https://earthexplorer. usgs.gov/). These data were pre-processed in ArcGIS 10.7 software for mosaic to one scene and re-projected to match the geographical co-ordinate system (UTM co-ordinate system - Datum: WGS 1984, Zone 36 North) for Integrity with the Landsat 8 OLI Scene.

The main part of the present study is geoheritage interpretation. First, all geomorphological, geological and geoarchaeological features identified are attributed to standard geoheritage types, according to the nomenclature proposed by Ruban $(2010,2020)$. Secondly, the uniqueness (heritage value) of these features is established; it can be local (area-restricted), regional (province-level), national (country-scale) or global (world rarity) (Ruban, 2010). Indeed, some features may be judged as ordinary (not unique), and, thus, these need to be excluded from the geoheritage of the study area. Thirdly, the locality is proposed as a geosite, the rank of which is determined by the uniqueness of the most valued (dominant) feature(s). Its accessibility, complexity to comprehension and present state (particularly, anthropogenic stress) are also addressed. Considerations of all of these require proper argumentation based on two kinds of reasoning, namely a comprehensive treatment of local geology and a comparison of the geoheritage of the study area to other areas in Egypt.

\section{Results}

The study area possesses potential geoheritage features, namely Djara Cave, fields and rings of

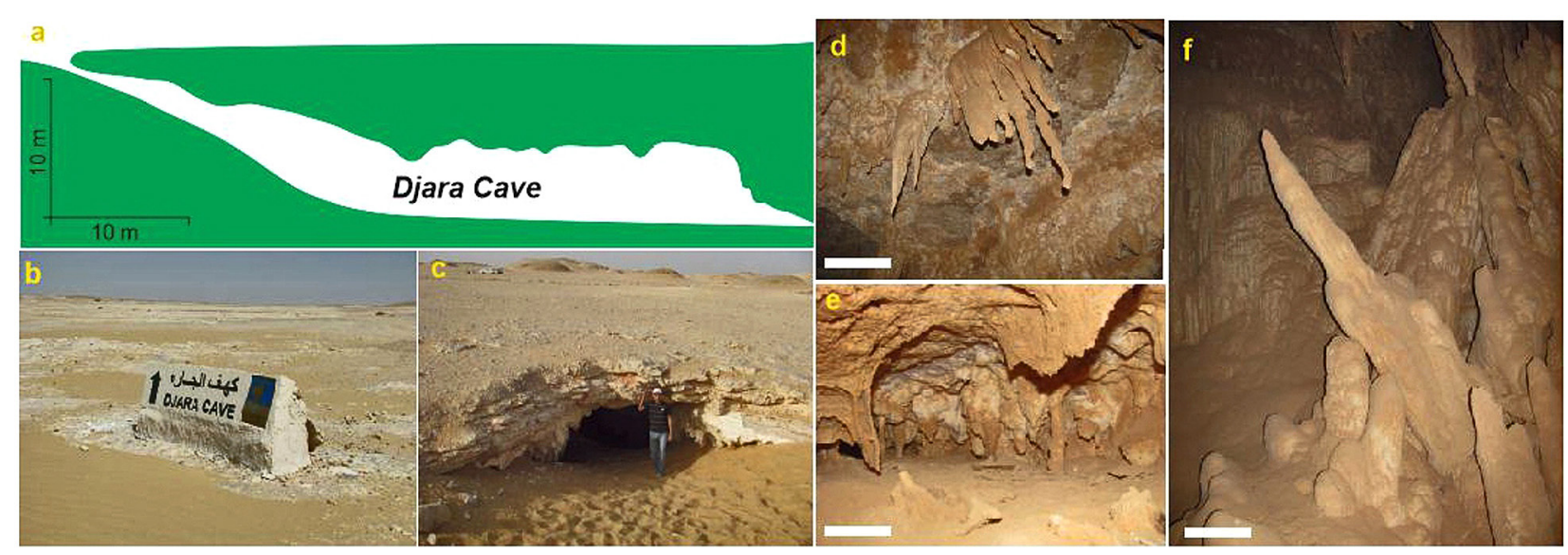

Fig. 2. Djara Cave: a - Longitudinal profile; b - Cave sign; c - Cave entrance; $\mathbf{d}-\mathbf{f}$ - Various speleothems (all scale bars $=10 \mathrm{~cm})$. 
weathered siliceous nodules, surface artefacts and dry drainage channels. These features are described and interpreted below.

Djara Cave has a narrow entrance at an absolute elevation of $194 \mathrm{~m}$ (Fig. 2a-c), which is close to average altitudes locally, as based on digital elevation models. Its setting was characterised by Classen et al. (2009). The cave is elongated, its length being $\sim 50 \mathrm{~m}$, and its depth does not exceed $13 \mathrm{~m}$. The cave profile is rather simple (Fig. 2a). Speleothems are fairly diverse and include both stalactites and stalagmites, some of which are inclined (Fig. 2d-f). In the so-called 'Large Hall', which is the main, sub-horizonthal chamber, stalactites predomintate and the cave floor is covered by several metres of sand. The cave resulted from karstification of Eocene limestones during wetter conditions of Pleistocene interglacial periods (or even earlier). The U-series ages for speleothems range between $283 \mathrm{ka}$ and $140 \mathrm{ka}$, and not one speleothem is younger than Pleistocene (Brook et al., 2002, 2003). The cave is famous for its rock art, with more than 100 engraved and/or pecked figures (Classen et al., 2009). These differ with regard to techniques used, in that some are more simplistic than others (Fig. 3a, b). There are figures of unrecognised cloven-hoofed animals, gazelles, antelopes, oryxes and ostriches, as well as humans. The rock art represents the past wildlife of the study area and its 'interaction' with early settlers in the Djara Depression during the Holocene climate optimum. At Djara Cave artefacts are rare (Classen et al., 2009).

This information allows to attribute Djara Cave to several geoheritage types, namely geomorphological (cave and speleothems as subsurface landforms), sedimentological (cave sand layers as highly specific deposit) and palaeogeographical (speleothems as archives of Pleistocene climate;
Brook et al., 2002, 2003) and rock art reflecting former human-environment interaction. Two additional remarks are called for. First, attribution of rock art to the palaeogeographical type of geoheritage corresponds to the understanding of this type by Bruno et al. (2014). Secondly, the hydro(geo) logical type cannot be established because hyper-arid conditions prohibit cave development via meteoric water in modern times. The uniqueness of the above-mentioned features differs. Caves are numerous across the globe, but are rare in Egypt (Brook et al., 2002; Vermeersch et al., 2005; Classen et al., 2009; Schmidt et al., 2015; Yousif et al., 2018; Kharbish et al., 2020; Sallam et al., 2020; Ruban et al., 2021). This means that its geomorphological features are of national geoheritage, in spite of the very moderate size of this cave. Cave rock art is rare on the country scale (Classen et al., 2009). However, the relative abundance of rock art in Egypt (Brétnont, 2018; Polkowski, 2018; AbdelMaksoud et al., 2020) needs to be taken into account. Apparently, this decreases the uniqueness of Djara Cave rock art. As far as speleothems are concerned, these rank among the numerous archives of Pleistocene environments in the Western Desert (e.g., Brook et al., 2003; Kieniewicz \& Smith, 2007; Wanas \& Armenteros, 2019), and their uniqueness is restricted. These lines of evidence imply that the heritage value of the palaeogeographical features is regional. Finally, sand is a deposit that is expected in an open, shallow and sub-horizonthal cave. This feature is not peculiar (Classen et al., 2009), and only the paucity of cave deposits in general permits to classify this as local geoheritage.

A notable feature found near Djara Cave comprises fields of siliceous nodules that at times look like rings (Fig. 4a, b). The nodules differ in shape, but often are spheroidal and polished (even erod-
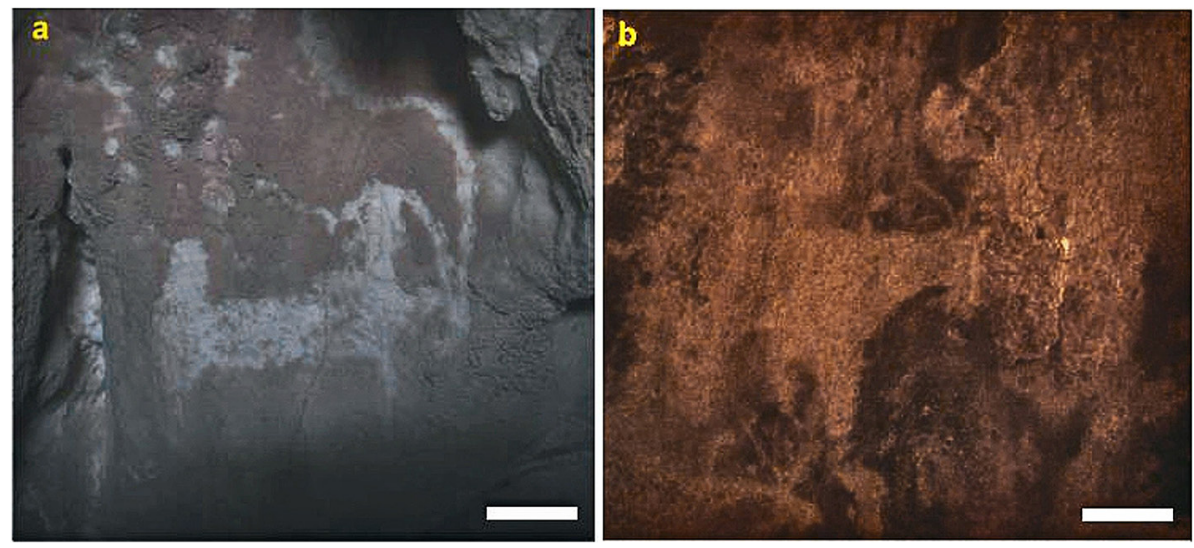

Fig. 3. Rock art in the Djara Cave: a - Simple ('primitive') gazelle drawing on the rock; $\mathbf{b}$ - Advanced drawing of gazelle with more details (all scale bars $=10 \mathrm{~cm}$ ). 
ed) by wind-blown sand; some exhibit rhythmically spaced bands that reflect growth stages (Fig. 4c). These nodules are fully or partly weathered from Eocene limestones. Formation of these nodules is linked to diagenetic processes, and their weathering results from the greater resistivity in comparison to the bedrock. These fields of siliceous nodules constitute a feature that can be assigned to the sedimentary type of geoheritage. The wide distribution of these nodules in the Western Desert and beyond (Shaaban, 2004) implies that this feature is of local uniqueness only.

Numerous artefacts have been found in the Djara Depression (Gehlen et al., 2002; Kindermann et al., 2006), and, particularly, near the cave. For instance, there are various lithic tools and pottery sherds (Fig. 4d), providing evidence of prehistoric land use of the study area, which can be interpreted in terms of regional climate change (Kindermann et al., 2006). Apparently, the Holocene humid optimum made this area suitable for non-sedentary human occupation. This evidence is, thus, palaeogeographically important and the artefacts noted can be assigned tentatively to the palaeogeographical type of geoheritage (sensu Bruno et al., 2014). However, the value of this feature is only local, and the evidence sheds light onto local mid-Holocene landscape exclusively.
Finally, a network of dry drainage channels should be noted. This is well visible on satellite images, and its presence is substantiated by higher-resolution digital elevation models. This network formed during Quaternary wet phases when rainwater discharged to local topographic lows, one of which was the Djara Depression (Kindermann et al., 2006). These features can be assigned to both geomorphological and palaeogeographical types of geoheritage. The wide distribution of such networks of dry drainage channels in desert areas of Egypt signifies that this feature is only local in value.

The presence of notable features with geoheritage value in the study area (Table 1) leads us to a geosite proposal. Undoubtedly, Djara Cave itself is the main geoheritage element, which matches the earlier notion of Embabi (2018). Although the heritage value of the cave vicinity is limited (Table 1), the relevant features are fairly diverse and abundant and contribute to our understanding of the geoheritage integrity of the Djara Depression. Consequently, it makes sense to propose the Djara geosite to include the cave and its vicinity. Provisionally, this can be delineated as a circle (radius $3 \mathrm{~km}$ ) with the cave in the centre. Such a large area is required to represent features reported from the surface near the cave, including part of the network of dry drainage chan-
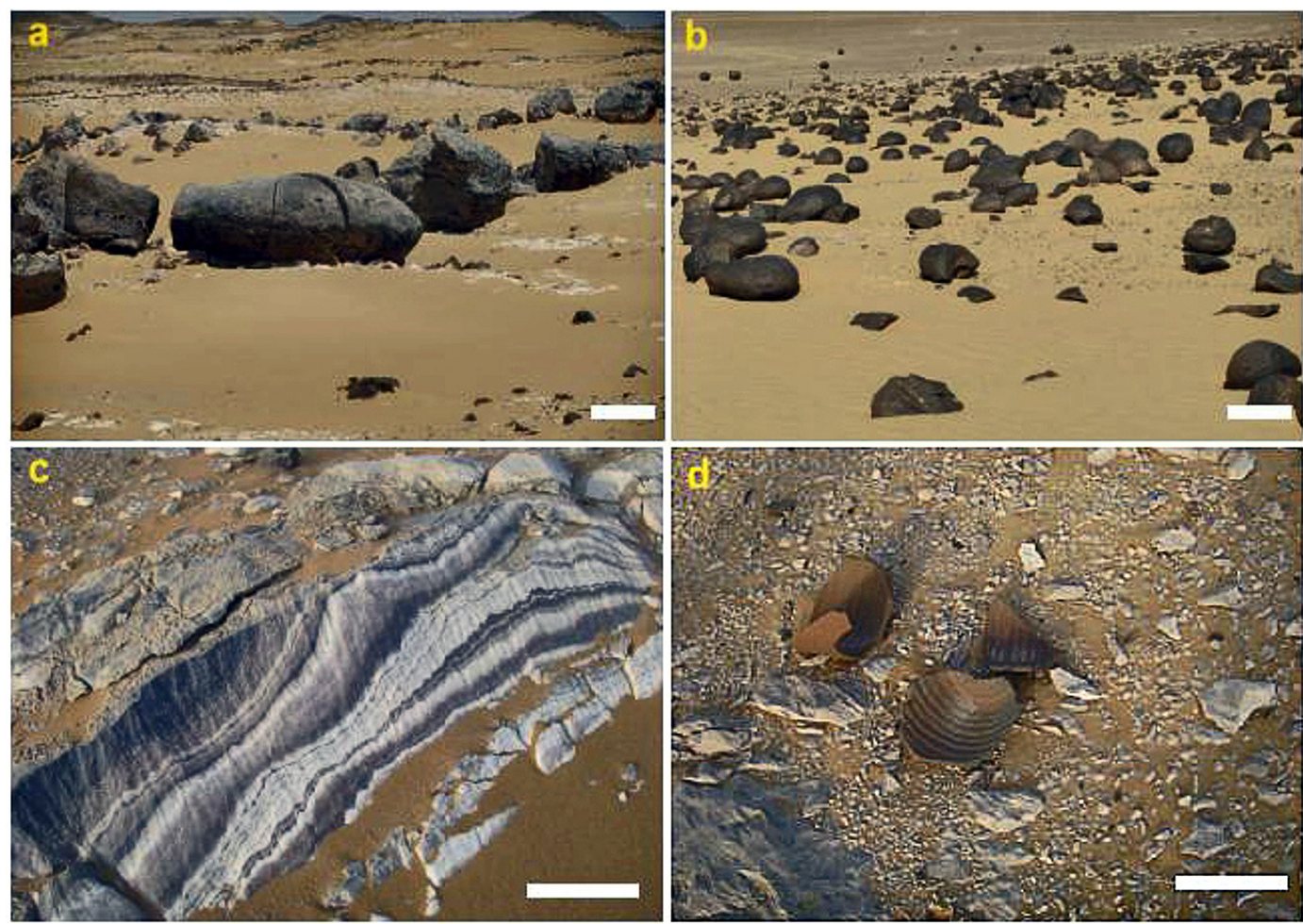

Fig. 4. Notable features in the vicinity of the Djara Cave: a, b - Siliceous nodules; $\mathbf{c}$ - Rhythmically-spaced bands of nodules; $\mathrm{d}$ - Potsherds (all scale bars $=10 \mathrm{~cm}$ ). 
Table 1. Geoheritage constituents in the study area.

\begin{tabular}{lcc}
\multicolumn{1}{c}{$\begin{array}{c}\text { Geoheritage types and } \\
\text { subtypes }\end{array}$} & \multicolumn{2}{c}{ Uniqueness } \\
\cline { 2 - 3 } & Djara Cave & Cave vicinities \\
\hline Geomorphological & National & Local \\
Sedimentological & Local & Local \\
Palaeogeographical & & \\
- palaeoenvironmental & Local & Local \\
- geoarchaeological & Regional & Local \\
\hline
\end{tabular}

nels, which is situated at a distance of $\sim 1-2 \mathrm{~km}$ from the cave. The rank of the proposed geosite is nation$\mathrm{al}$, to reflect the value of the dominant geomorphological type (Table 1). Evidently, this geosite is also a geomorphosite (sensu Panizza, 2001; Reynard et al., 2011, 2016). The accessibility to this geosite is mixed. On the one hand, it is located in the central part of the Western Desert and quite distant from populated places. Visitors first need to reach Bahariya Oasis, which lies $\sim 200 \mathrm{~km}$ to the north of Djara Cave, and then make their way to the cave via unpaved roads. On the other, the locality itself is easily studied, and visits of the cave do not require special equipment or serious safety precautions. Comprehension of this proposed geosite is challenging. Special interpretations are called for so as to explain its origin in the modern desert and its relevance to documentation of wetter palaeoenvironments, to reveal the nature of siliceous nodules and to pay attention to cave rock art. The last-named feature is not easily visible (Fig. 4) and requires professional deciphering (Classen et al., 2009). However, this complexity does not lower the geosite rank. The cave remains in a fairly stable state at present, but anthropogenic stress is inevitable, and can be linked to occasional damage of speleothems and rock art, uncontrolled collection of artefacts and waste dumping by visitors. In spite of its remote location, Djara Cave is visited fairly actively by tourists, and absence of protection status and unlimited access make it highly vulnerable to anthropogenic stress. Its present state can be judged to be stable, but in risk.

\section{Discussion}

Geoheritage constitutes an important natural (geological) resource, which can be exploited for the purposes of science, education and tourism (Ehsan et al., 2013; Brilha, 2016; Bétard et al., 2017; Brilha et al., 2018; Santangelo \& Valente, 2020). The utility of the proposed Djara geosite can be analysed in the light of available information. The scientific community is relatively well aware of this locality and its geological, geomorphological and geoarchaeological peculiarities, which have been studied fairly regularly (Brook et al., 2002, 2003; Kindermann et al., 2006; Classen et al., 2009; Embabi, 2018). Although speleothem-based palaeoenvironmental interpretations and rock art deciphering have been completed successfully, Djara Cave remains a reference point for relevant ongoing studies in the Western Desert. Education utility is low due to the remoteness, complexity, absence of interpretative signs, and restricted diversity of the locality. The tourism utility of Djara Cave is moderate in that this geosite is too remote from popular tourist destinations in Egypt and lacks tourism infrastructure. Its aesthetic properties are evident and linked to the spectacular cave speleothems. However, with regard to the entity of parameters for tourist judgements of beauty (Kirillova et al., 2014), the relatively small size of the cave, restricted diversity of unique features and limited visibility of rock art (Fig. 2) have a negative impact on the aesthetic value of the cave. Djara Cave is actively visited by tourists already and even promoted as a unique tourist attraction in Egypt (Table 2). Apparently, the proposed geosite can attract both trained geotourists interested in the rich geoheritage of the Western Desert, including the Bahariya and Farafra oases and some other localities (Plyusnina et al., 2016), and many other tourists, including adventure tourists, interested in the wild nature of the Sahara. The premises for exploitation of Djara-related geoheritage are summarised in Table 3 .

Table 2. Selected tourism-related information about the Djara Cave available on-line.

\begin{tabular}{|c|c|c|}
\hline Type of information & Focus & URL \\
\hline Tour program & $\begin{array}{l}\text { Four-days tour to the Western } \\
\text { Desert with a short cave visit }\end{array}$ & $\begin{array}{l}\text { https://www.westerndeserttours.com/tours-services/djara- } \\
\text { cave-4-days/ }\end{array}$ \\
\hline Travelogue & $\begin{array}{l}\text { Individual experience of visit- } \\
\text { ing the cave }\end{array}$ & $\begin{array}{l}\text { https://www.amcham.org.eg/publications/busines } \\
\text { ly/issues/272/August-2018/3763/the-road-to-djara- }\end{array}$ \\
\hline Tour & Opportunities to visit the cave & $\begin{array}{l}\text { https:// www.privatetoursinegypt.com/Djara-cave-attrac- } \\
\text { tion56 }\end{array}$ \\
\hline Tourism firm note & Cave description & $\begin{array}{l}\text { https://www.desertegyptsafari.com/egypt-western-desert- } \\
\text { djara-cave/ }\end{array}$ \\
\hline Touri & Cave & https://www.etltravel.com/farafra-oasis/djara-cave-egypt/ \\
\hline Tourism firm note & $\begin{array}{l}\text { Cave description and opportu- } \\
\text { nities to visit the cave }\end{array}$ & $\begin{array}{l}\text { https://www.cairotoptours.com/Egypt-Travel-Guide/Oases- } \\
\text { of-Egypt/Gara-Cave }\end{array}$ \\
\hline
\end{tabular}


Table 3. Exploitation potential of the proposed Djara geosite.

\begin{tabular}{|c|c|}
\hline Issue & Explanation \\
\hline \multicolumn{2}{|c|}{ Geoconservation } \\
\hline Official status & $\begin{array}{l}\text { Requiring designation as a } \\
\text { protected site }\end{array}$ \\
\hline Control of cave access & Unlimited access \\
\hline \multicolumn{2}{|c|}{ Geoscience } \\
\hline $\begin{array}{l}\text { Awareness of scientific } \\
\text { community }\end{array}$ & Moderate, international \\
\hline $\begin{array}{l}\text { Regularity of scientific } \\
\text { assessment }\end{array}$ & $\begin{array}{l}\text { Moderate, several studies } \\
\text { published }\end{array}$ \\
\hline \multicolumn{2}{|c|}{ Geoeducation } \\
\hline Diversity of phenomena & $\begin{array}{l}\text { Low-to-moderate (see } \\
\text { Table 1) }\end{array}$ \\
\hline $\begin{array}{l}\text { Simplicity/complexity of } \\
\text { phenomena }\end{array}$ & $\begin{array}{l}\text { Requiring professional } \\
\text { interpretation }\end{array}$ \\
\hline $\begin{array}{l}\text { Information signs, panels, } \\
\text { etc. }\end{array}$ & Too few \\
\hline \multicolumn{2}{|c|}{ Geotourism } \\
\hline Awareness of tourists & Low-to-moderate \\
\hline $\begin{array}{l}\text { Potential for occasional } \\
\text { (geo)tourists }\end{array}$ & Moderate \\
\hline Aesthetic value & Moderate \\
\hline $\begin{array}{l}\text { Tourism-related infra- } \\
\text { structure }\end{array}$ & Requiring construction \\
\hline Geopark creation potential & $\begin{array}{l}\text { Absent due to restricted } \\
\text { geoheritage diversity }\end{array}$ \\
\hline $\begin{array}{l}\text { Tourism significance of the } \\
\text { region }\end{array}$ & Low-to-moderate \\
\hline $\begin{array}{l}\text { Distance for highly-de- } \\
\text { manded destinations }\end{array}$ & Significant \\
\hline $\begin{array}{l}\text { Possibility for integration } \\
\text { with the other tourism } \\
\text { programs and initiatives }\end{array}$ & $\begin{array}{l}\text { Significant (general tours } \\
\text { and geotours to the West- } \\
\text { ern Desert) }\end{array}$ \\
\hline Risks & $\begin{array}{l}\text { Occasional damage of cave } \\
\text { and its rock art }\end{array}$ \\
\hline Other attractions & Archaeological \\
\hline
\end{tabular}

Djara Cave can be compared to Sannur Cave near Beni Suef in Egypt that has been studied comprehensively by Sallam et al. (2020). Although both caves are essentially similar objects, many differences between them can be established. In particular, Sannur Cave boasts a higher-rank (global), wider diversity of heritage features, significant heritage value of features outside the cave, better accessibility, higher aesthetic properties and an established protection status with access limitations. Geopark creation is recommended for Sannur Cave, whereas geosite status would appear to be sufficient for Djara Cave. With regard to the differences listed, these two objects do not compete with one another for geoconservation and geotourism attention. Nonetheless, the presence of these and a few other caves on the territory of Egypt (see Table 3 in Sallam et al., 2020), as well as their utility (especially for the purpose of country-scale tourist growth and diversification) require recognition of a special category of geoheritage, namely speleological heritage (sensu Lobo \& Moretti, 2009; Brandi et al., 2019; Antic et al., 2020) on a national level. This would permit to plan and implement strategies of effective conservation of Djara and Sannur caves, and others, in Egypt.

As far as observations made in the study area are concerned, three urgent practical recommendations can be listed for the Djara geosite proposed. First, official protection status should be assigned to the geosite or to Djara Cave. Secondly, uncontrolled visits of the cave should be limited, and thirdly, interpretative signs/panels explaining local geology, geomorphology and geoarchaeology need to be installed. Undoubtedly, promotion of this attraction by tourist firms (Table 2) deserves appreciation, but these firms need to be aware of the full heritage value of this locality and its vulnerability to anthropogenic stress. The relevant information needs to be distributed among these firms by state officials.

\section{Conclusions}

Our assessment of the geoheritage of Djara Cave and its vicinity allows drawing three general conclusions:

- the geoheritage of the study area includes geomorphological, sedimentological and palaeogeographical features, and is linked to archaeological heritage;

- the proposed geosite that includes Djara Cave and nearby surface features is of national rank, and is useful for science, education and especially tourist purposes;

- the proposed geosite needs official status and geoconservation measures in view of its vulnerability to anthropogenic stress and demands professional interpretation of its unique features. In more general terms, the present study contributes to our knowledge of valuable geological resources of the Western Desert of Egypt, namely geoheritage. Exploitation of these resources can facilitate local sustainable development through scientific investigations, educational programmes, growth of tourism and diversification of remote desert areas in Egypt. The relevant initiatives lead to accumulation of intellectual capital, infrastructural development, additional income to local communities, careful nature management and effective place branding. Further investigations should aim at geoheritage identification and assessment in the entire 
Western Desert in order to continue exploration of the resources noted and to determine the most suitable approaches to its exploitation.

\section{Acknowledgements}

The authors are grateful to the editor and the journal reviewers for thorough screening of the manuscript and helpful recommendations.

\section{References}

AbdelMaksoud, K.M., Elfeky, H., Ruban, D.A. \& Ermolaev, V.A., 2020. A Unique Coincidence of Geomorphological, Geological, and Geoarchaeological Features in the Valley of Camels (Dakhla Oasis, Western Desert, Egypt). Geoheritage 12, 81.

Antic, A., Tomic, N., Đordevic, T., Radulovic, M. \& Đevic, I., 2020. Speleological objects becoming show caves: evidence from the Valjevo karst area in Western Serbia. Geoheritage 12, 95.

Ballesteros, D., Fernández-Martínez, E., Carcavilla, L. \& Jiménez-Sánchez, M., 2019. Karst Cave Geoheritage in Protected Areas: Characterisation and Proposals of Management of Deep Caves in the Picos de Europa National Park (Spain). Geoheritage 11, 1919-1939.

Bétard, F., Hobléa, F. \& Portal, C., 2017. Geoheritage as new territorial resource for local development. Annales de Geographie 717, 523-543.

Brandi, I.V., Barbosa, M.R., Guimarães de Paula, R., Araújo, R.N., Vieira de Moura, R.S. \& Mota de Lima, H., 2019. Instrumented geotechnical monitoring of a natural cave in a near mine operation - Towards a sustainable approach to mining and preservation of speleological heritage. Journal of Cleaner Production 239,118040 .

Brétnont, A., 2018. Elephants, hippos and mouflons. Three hypotheses of animal markers of regional identities during the periods of Nagada I-II. Archeo-Nil 28, 69-98.

Brilha, J., 2016. Inventory and quantitative assessment of geosites and geodiversity sites: a review. Geoheritage 8, 119-134.

Brilha, J., Gray, M., Pereira, D.I. \& Pereira, P., 2018. Geodiversity: An integrative review as a contribution to the sustainable development of the whole of nature. Environmental Science and Policy 86, 19-28.

Brook, G.A., Embabi, N.S., Ashour, M.M., Edwards, R.L., Cheng, H., Cowart, J.B. \& Dabous, A.A., 2002. Djara Cave in the Western Desert of Egypt: Morphology and evidence of Quaternary climatic change. Cave and Karst Science 29, 57-66.

Brook, G.A., Embabi, N.S., Ashour, M.M., Lawrence Edwards, R., Cheng, H., Cowart, J.B. \& Dabous, A.A., 2003. Quaternary environmental change in the Western Desert of Egypt: Evidence from cave speleothems, spring tufas, and playa sediments. Zeitschrift für Geomorphologie, Supplementband 131, 59-87.

Brookes, I.A., 2001. Aeolian erosional lineations in the Libyen Desert, Dakhla Region, Egypt. Geomorphology 39, 189-209.

Brookes, I.A., 2003. Geomorphic indicators of Holocene winds in Egypt's Western Desert. Geomorphology 56, 155-166.

Bruno, D.E., Crowley, B.E., Gutak, J.M., Moroni, A., Nazarenko, O.V., Oheim, K.B., Ruban, D.A., Tiess, G. \& Zorina, S.O., 2014. Paleogeography as geological heritage: Developing geosite classification. Earth-Science Reviews 138, 300-312.

Classen, E., Kindermann, K. \& Pastoors, K., 2009. Djara - Cave Art in Egypt's Western Desert. Archeo-Nil 19, 47-66.

Čech, V., Chrastina, P., Gregorová, B., Hronček, P., Klamár, R. \& Košová, V., 2021. Analysis of attendance and speleotourism potential of accessible caves in karst landscape of Slovakia. Sustainability 13, 5881.

Ehsan, S., Shafeealeman, M. \& Arabegum, R., 2013. Geotourism: A tool for sustainable development of geoheritage resources. Advanced Materials Research 622, 1711-1715.

Embabi, N.S., 2018. Geo-Parks and Features of Geomorphic and Geologic Significance. Landscapes and Landforms of Egypt. World Geomorphological Landscapes. Springer, Cham, https:/ / doi.org/10.1007/9783-319-65661-8_23.

Garofano, M. \& Govoni, D., 2012. Underground Geotourism: A Historic and Economic Overview of Show Caves and Show Mines in Italy. Geoheritage 4, 79-92.

Gehlen, B., Kindermann, K., Linstädter, J. \& Riemer, H., 2002. The Holocene Occupation of the Eastern Sahara: Regional Chronologies and Supra-regional Developments in four Areas of the Absolute Desert. In: Tides of the Desert - Gezeiten der Wüste. Contributions to the Archaeology and Environmental History of Africa in Honour of Rudolph Kuper. Heinrich-Barth-Institut, Köln, pp. 85-116.

Golonka, J., 2004. Plate tectonic evolution of the southern margin of Eurasia in the Mesozoic and Cenozoic. Tectonophysics 381, 235-273.

Guiraud, R., Bosworth, W., Thierry, J. \& Delplanque, A., 2005. Phanerozoic geological evolution of Northern and Central Africa: An overview. Journal of African Earth Sciences 43, 83-143.

Kharbish, S., Henaish, A. \& Zamzam, S., 2020. Geodiversity and geotourism in Greater Cairo area, Egypt: implications for geoheritage revival and sustainable development. Arabian Journal of Geosciences 13, 451.

Kieniewicz, J.M. \& Smith, J.R., 2007. Hydrologic and climatic implications of stable isotope and minor element analyses of authigenic calcite silts and gastropod shells from a mid-Pleistocene pluvial lake, Western Desert, Egypt. Quaternary Research 68, 431-444.

Kindermann, K., Bubenzer, O., Nussbaum, S., Riemer, H., Darius, F., Pöllath, N. \& Smettan, U., 2006. Palaeoenvironment and Holocene land use of Djara, Western Desert of Egypt. Quaternary Science Reviews 25, 16191637. 
Kirillova, K., Fu, X., Lehto, X. \& Cai, L., 2014. What makes a destination beautiful? Dimensions of tourist aesthetic judgment. Tourism Management 42, 282-293.

Lewis, I.D., 2019. South Australian geology and the State Heritage Register: an example of geoconservation of the Naracoorte Caves complex and karst environment. Australian Journal of Earth Sciences 66, 785-792.

Lobo, H.A.S. \& Moretti, E.C., 2009. Tourism in caves and the conservation of the speleological heritage: The case of Serra da Bodoquena (Mato Grosso do Sul state, Brazil). Acta Carsologica 38, 265-276.

Lobo, H.A.S. \& Boggiani, P.C., 2013. Caves as geological heritage. Boletim Paranaense de Geosciencias 70, 190199.

Mikhailenko, A.V., Ruban, D.A. \& Ermolaev, V.A., 2021. Accessibility of geoheritage sites - a methodological proposal. Heritage 4, 1080-1091.

Mügge, V., Rosendahl, W. \& Wrede, V., 2007. On the meaning of cave and karst for the Ruhr Area National GeoPark. Mitteilungen des Verbandes der Deutschen Hohlen- und Karstforscher 53, 36-40.

Panizza, M., 2001. Geomorphosites: Concepts, methods and examples of geomorphological survey. Chinese Science Bulletin 46, 4-6.

Paunovic, M., 1996. Vindija Cave (Croatia) - site of fossil man (proposal for inclusion in the World Geological Heritage List). Geologica Balcanica 26, 15-24.

Plyusnina, E.E., Sallam, E.S. \& Ruban, D.A., 2016. Geological heritage of the Bahariya and Farafra oases, the central Western Desert, Egypt. Journal of African Earth Sciences 116, 151-159.

Polkowski, P.L., 2018. Working on Rock Art in the Dakhleh Oasis: Some Thoughts on Threats to Petroglyphs and Possibilities of Research in the Western Desert, Egypt. African Archaeological Review 35, 191210.

Polukhina, A.N., Lyakhnitsky, Y.S. \& Lezhnin, V.V., 2019. The concept of regulated use of natural heritage sites included in the tourist cluster: A Russian caves case study. Journal of Cave and Karst Studies 81, 162-173.

Prosser, C., Murphy, M. \& Larwood, J., 2006. Geological conservation: a guide to good practice. English Nature, Peterborough, $145 \mathrm{pp}$.

Reynard, E. \& Brilha, J. (Eds.), 2018. Geoheritage: Assessment, Protection, and Management. Elsevier, Amsterdam, 482 pp.

Reynard, E., Coratza, P. \& Giusti, C., 2011. Geomorphosites and Geotourism. Geoheritage 3, 129-130.

Reynard, E., Coratza, P. \& Hobléa, F., 2016. Current Research on Geomorphosites. Geoheritage 8, 1-3.

Ruban, D.A., 2010. Quantification of geodiversity and its loss. Proceedings of the Geologists' Association 121, 326-333.

Ruban, D.A., 2018. Karst as Important Resource for Geopark-Based Tourism: Current State and Biases. Resources 7, 82.

Ruban, D.A., 2020. Geological Heritage of the Anthropocene Epoch - A Conceptual Viewpoint. Heritage 3, 19-28.

Ruban, D.A., Sallam, E.S., Khater, T.M. \& Ermolaev, V.A., 2021. Golden Triangle Geosites: Preliminary Geoher- itage Assessment in a Geologically Rich Area of Eastern Egypt. Geoheritage 13, 54.

Said, R. (Ed.), 2017. The geology of Egypt. Routledge, London, 734 pp.

Sallam, E.S., Ruban, D.A., Mostafa, M.T., Elkhodery, M.K., Alwilily, R.L., Molchanova, T.K. \& Zorina, S.O., 2020. Unique desert caves as a valuable geological resource: first detailed geological heritage assessment of the Sannur Cave, Egypt. Arabian Journal of Geosciences $13,141$.

Santangelo, N. \& Valente, E., 2020. Geoheritage and Geotourism resources. Resources 9,80 .

Schmidt, C., Kindermann, K., van Peer, P. \& Bubenzer, O., 2015. Multi-emission luminescence dating of heated chert from the Middle Stone Age sequence at Sodmein Cave (Red Sea Mountains, Egypt). Journal of Archaeological Science 63, 94-103.

Shaaban, M.N., 2004. Diagenesis of the lower Eocene Thebes Formation, Gebel Rewagen area, Eastern Desert, Egypt. Sedimentary Geology 165, 53-65.

Stephens, M., Hodge, S. \& Paquette, J. .2013. Geoconservation of Volivoli Cave, Fiji: A Prehistoric Heritage Site of National Significance. Geoheritage 5, 123-136.

Štrba, L, Rybár, P., Baláž, B., Molokác, M., Hvizdák, L., Kršák, B., Lukác, M., Muchová, L., Tometzová, D. \& Ferencíková, J., 2015. Geosite assessments: comparison of methods and results. Current Issues in Tourism 18, 496-510.

Urban, J., 2004. Caves and karst sites of Poland as a contribution to geological heritage of Central Europe. Polish Geological Institute Special Papers 13, 89-96.

Vermeersch, P.M., Van Peer, P., Rots, V. \& Paulussen, R., 2005. A survey of the Bili Cave and its surroundings in the Red Sea Mountains, El Gouna, Egypt. Journal of African Archaeology 3, 267-276.

Wanas, H.A. \& Armenteros, I., 2019. Microbially-induced fluvial tufa in Gunna hills, Farafra Oasis, Egypt: Facies analysis and stable isotopes. Journal of African Earth Sciences 158, 103515.

Warowna, J., Zglobicki, W., Kolodynska-Gawrysiak, R., Gajek, G., Gawrysiak, L. \& Telecka, M., 2016. Geotourist values of loess geoheritage within the planned Geopark Malopolska Vistula River Gap, E Poland. Quaternary International 399, 46-57.

Wei, Y.-L., Chen, W.-H., Luo, Q.-K., He, Z.-F. \& Tan, Z.Q., 2016. Characteristics and formation and evolution analysis of the karst landscape of Zhijindong Cave Global Geopark, Guizhou Province. Acta Geoscientica Sinica 37, 368-378.

Woo, K.S., Kim, L., Ji, H., Jeon, Y., Ryu, C.G. \& Wood, C., 2019. Geological Heritage Values of the Yongcheon Cave (Lava Tube Cave), Jeju Island, Korea. Geoheritage 11, 615-628.

Yousif, M., Henselowsky, F. \& Bubenzer, O., 2018. Palaeohydrology and its impact on groundwater in arid environments: Gebel Duwi and its vicinities, Eastern Desert, Egypt. Catena 171, 29-43

Manuscript submitted: 17 May 2021 Revision accepted: 25 July 2021 